\title{
A Review of Bank Loans to Farmers: Implications for Agricultural Diversification in Nigeria
}

\author{
Sebastian 0 Uremadu ${ }^{1 *}$ and Charity E Duru Uremadu ${ }^{2}$ \\ ${ }^{1}$ Department of Banking \& Finance, Michael Okpara University of Agriculture, Nigeria \\ ${ }^{2}$ Department of Educational Management, Michael Okpara University of Agriculture, Nigeria
}

Submission: April 30, 2018; Published: May 21, 2018

"Corresponding author: Sebastian 0 Uremadu, Department of Banking \& Finance, Michael Okpara University of Agriculture, Nigeria; Tel: +234-8037876614; Email: sebauremadu@yahoo.com

\begin{abstract}
Paper examined core issues inherent in agricultural loans to farmers using fundamental analysis method in its discussions and analysis. First, paper considered factors contributing to high risks in agricultural lending and how to manage them, second, factors of non-financial commercial bank lending were treated and third, financial factors considered by banks in making loans have been examined. In all, these factors and their implications to agricultural diversification of the Nigerian economy were discussed with a view to enhancing the agricultural productivity that would launch Nigeria into self-sufficiency in food production and exports in the $21^{\text {st }}$ century.
\end{abstract}

\section{Introduction}

Loans to farmers were amongst the earliest loans made by commercial banks. Although commercial banks had continued to extend credits to farmers, direct loans to farmers account for a smaller proportion of total loans. Bank loans to farmers with other loans such as business, consumer and real estate loans rank least when compared to other loans [1].

How important farm loans are to a given bank depends, of course, on the bank's location and its lending policies. Thus, banks located in states where agriculture is an important industry extend the largest amount of farm credit.

\section{Discussions on Factors Considered on Agricultural Lending to Farmers}

Factors contributing to the risks in agricultural lending

Loans to farmers generally carry more risks than do loans to other forms of businesses. To some extent, this discourages banks from expanding their farm loans and results in relatively short maturities for most of the loans granted. The risk factors attached to farm loans are unfavourable cost-price relationship that exists for major agricultural products [2].

The second is the difficulty of serving adequate information about farming operations. Thirdly, is the fact that in many cases, farming is a family and not a commercial enterprise. All these factors constitute risk factors in lending agricultural loans.
The unfavourable cost-price relationship is a product of the relatively inelastic demand for agricultural products. A small increase in supply is accompanied by a sharp decrease in price and a relatively elastic supply. That is, a slight increase in price is accomplished by a sharp increase in supply. This situation has resulted in a highly fluctuating income from which debts are repaid. Farmers react differently to price changes than do other business units. In periods of low prices, other business units usually curtail output; sometimes, by temporarily permanent suspension of operations or even by insolvency.

Famers have reacted quite differently to lower prices. They have actually stepped up production during periods of low prices. This has resulted in more farm products being placed on the market at reduced prices since the demand for agricultural commodities is highly inelastic. As a result of increased production and lower prices, farm income falls.

Agricultural price instability is also encouraged by factors beyond the control of farmers such as weather conditions. There are years of bountiful harvest and years of scarcity. Moreover, the cycle of agricultural production which is longer than in most other lines of economic activities contribute to price instability. Farmers are unable to quickly curtail or expand some types of production. Livestock, for instance, cannot be increased or decreased overnight within any few weeks or even months; therefore relatively insensitive in the short-run to price changes. This, in turn, causes variable farm income. 
The instability of farm income makes agricultural credits uncertain. Commercial banks may be able to judge with reasonable accuracy the other factors important in credit analysis and extension, but farm income is difficult to predict with any degree of accuracy [3].

This risk has contributed to commercial banks reducing their participation in agricultural lending especially in long-term loans. This gap has been filled by other lenders who require less liquidity and by government lending agencies (ie, specialized agencies that fund agricultural credits). Sometimes, it is difficult to obtain many important facts to analyse a farmer's credit worthiness. Farming is an industry of small business units and majority of farms may be classified as subsistence operations. Under such conditions, farm operators are more interested in making both ends meet than in keeping records. Consequently, production, marketing and financial data that will support credit analysis are often not available. This is not true of all farm operations, particularly not of large commercial farms. In general, operators of these farms keep reliable records of their operations so that credit analysis is relatively simple.

Finally, a large proportion of farm operations in Nigeria is carried on as a family enterprise. As a result, it becomes difficult, if not impossible, to distinguish between the costs of operating the farm and the living expenses of the family. If the fanner has had a good year, durable consumer items for the family may be purchased and if the year is a bad year, consumption comes first and it is doubtful if any of the income will be set aside for repayment of the machinery, improving the livestock or for land improvement.

Borrowing may be for productive or consumption purposes and in many cases, the purpose is impossible to distinguish. Because of all these factors, farmers over the years have encountered some difficulties in securing bank credit and to alleviate this situation, various government programmes have been introduced. Among them is the credit guidelines enforced on the banks to lend to the farmers. Another is the low rate of interest charged on farm loans. Still another, is the Guaranteed Credit Scheme (e.g. Government guaranteed 75 percent and 25 percent is not guaranteed, and the banks stand to bear this risk).

\section{Factors of non-financial commercial bank lending}

Some aspects of commercial bank lending to farmers stress need to employ one or more farm representatives in the bank. It is farm representative's job to know agricultural production and processes, the farmers in the area and their problems and to serve as agricultural counsellor. Such a representative works outside the bank a great part of his time. He is seen in the fields, not in air-conditioned offices, at trade and agricultural fairs talking to farmers about their problems, providing information, giving advice, both financial and technical. He co-operates with the extension services and with the various farming clubs and organizations who wish to increase agricultural production by the efficient use of land and machinery and facilitate the introduction of new methods. He is the head of the bank's promotional farm programme whatever it may be.

The purpose of the farm representative's activity is to generate loans that meet the bank's standard of quality and maturity. The bank's standards of quality and maturity. The representative does not disassociate himself from those farmers who are not borrowing from his bank because his services may result in some of these farmers becoming his bank's customers. For-instance, a farmer may need a real estate loan of a maturity beyond that acceptable to his bank, so the farm representatives may help him contact the mortgage bank or a life insurance company specialising in such loans. The next time the farmer needs credit, he may contact the bank's farm representative again and this loan may fit the bank's requirements [4].

Commercial banks are very selective in their agricultural loans, but they are eager to make those loans that have appropriate qualifications. In lending to farmers, bankers are interested in many things including the applicant's credit character, management abilities and net-worth. The appropriateness of his equipment and machinery and the productivity of the soil, the borrower's honesty and integrity are basic components in any loan and the agricultural loans are no exceptions.

The ability to manage a farm is obviously important and it is in the applicant's education and training, past experience, industry and thrift. Those applicants who shrink from starting at $4.00 \mathrm{a} . \mathrm{m}$. or choose an evening of leisure in preference to ploughing the field when that needs to be done because of an unusual rainy season are probably not well received by the bank as those willing to earn their bread by hard work. Hard work does not guarantee results, but it is an essential ingredient to success on a farm. For more than farming, farm operators must have equipments designed for the job to be performed. Those who do not are placed at least competitive advantage. Banks that are efficient farm lenders satisfy themselves that applicants have the tools with which to work. Knowing this information is the responsibility of the farm representative.

The productivity of the soil is also a factor that bank lending officer consider in farm lending; poor land is obviously less productive than a rich land, and in general requires as much labour and capital in the productive process. Not only must the farm be adequately productive, but the farm operator should also have improvement by the use of fertilizers, crop rotation and other methods available to farmers. When a farmer applies for a loan, the banker wants, besides financial information, projections regarding acres to be cultivated, the number of cattle to be fed or milked and the number of horses expected to be harrowed. The fanner himself should not attempt more than he can handle, but a farm like any other business must be operating at a near capacity for efficient operation and income generation. For farms that must rely on hired labour at times during the production process, a supply should be re-arranged since insufficient labour may result in serious crop losses. 


\section{Financial factors considered by commercial banks in making loans}

The most important financial factor to be considered by a banker before he grants farm loan is the farmer's ability to generate positive cashflows from his farm operations and the positive cashflows exist when the amount received from a given period exceeds the amount expended. Cashflow is not synonymous with profit for it takes account of money received from all sources including sale of capital assets, new borrowings, etc., and the expenditure for all purposes including payments for capital equipments for debt reduction and to meet living expenses. Thus cashflow may be positive while the farm is being operated at a loss. Of course, cashflow cannot be positive for many years if the farm is never profitable. A positive cashflow during a period of a negative profit means a decrease in assets and increase in liabilities or both with a corresponding decrease in networth. After a number of unprofitable operations, the farmer's ability to generate a positive cashflow will be destroyed because of inadequate equipment and too much debt.

For any given period of operations, however, if a farmer can produce a sufficient cashflow to repay a loan after providing for essential farm expenditures and family needs, credit should be made available to him.

The farmer's networth is of less importance in the loan granting decision even though the farmer owns all his land and equipment unencumbered, if he cannot operate the farm to produce an adequate cashflow, he does not deserve bank accommodation. Indeed, the bank is relatively certain of repayment by forcing liquidation of some of the farmer's assets, but this is undesirable. The primary reason for taking a security for a loan is to help assure repayment in cash and not through liquidation of the security [3].

Networth and cashflow are not unrelated. If a farmer has a small networth, he is financing much of his operations with debts. The interest and principal payments on the debt constitute a portion of his cashflow and thus reduce the likeliness of a positive cashflow. This, in turn, makes it more difficult to obtain additional credit and the loans that are granted at a higher rate than if his networth were larger.

\section{Summary of Findings, Recommendations and Conclusion}

\section{Summary of findings}

From the above foregoing discussions, we can establish the followings as findings of research:

1. Among the risk factors attached to farm loans are unfavourable cost-price relationship that exists for major agricultural products and the difficulty of serving adequate information about farming operations.

2. Study also established that some aspects of bank lending to farmers stress the need to employ one or more farm representative in the bank whose job is to know agricultural production processes, the farmers in the area and their problems and to serve as agricultural counsellor.

3. Study discovered that the purpose of the farm representative's activity is to generate loans that meet the bank's standards of quality and maturity.

4. Paper also established that commercial banks are very selective in their agricultural loans, but they are very eager to make those loans that have appropriate qualifications.

5. Ability to effectively manage a farm is also a factor in farm lending. The ability to manage a farm is obviously important and is reflected in the applicant's education and training, past experience, industry and thrift [3].

6. Again, study established that the productivity of the soil is a factor that bank lending officers consider in farm lending.

7. Study discovered that the most important factor to be considered by a banker before he grants farm loan is the farmer's ability to generate positive cashflows from his farm operations and the positive cashflows exist when the amount received from a given period exceeds the amount expended.

8. Finally, paper found out that the famer's networth is of less importance in the loan granting decision even though the farmer owns all his land and equipment unencumbered, if he cannot operate the farm to produce an adequate cashflow, he does not deserve bank accommodation.

\section{Recommendations and conclusion}

Based on the findings of this paper, we shall make quick to recommend the followings for urgent policy action hereunder;

1. That government should intervene in agricultural lending to farmers with a sole objective to ameliorate most risk factors inherent in agricultural loans such as unfavourable cost-price relationship existing in major agricultural products, mobilize agricultural extension workers in a bid to remove difficulty of serving adequate information about farming operations to farmers.

2. Bank regulators should ensure that banks recruit and train enough farm representatives in the bank who would serve as agricultural counsellors to farmers in the area and the problems.

3. That commercial banks should ensure that farm representatives generate loans that meet bank's standards of quality and maturity; and give out those loans that have appropriate qualifications.

4. Banks should look for farmers with requisite ability to manage a farm for loans which is reflected in the applicant's education and training, past experience, industry and thrift.

5. Government should subsidize fertilizers to farmers to engender productivity of the soil which is a factor that bank lending officers consider in farm lending. 
6. Finally, famers themselves should always endeavour to generate positive cashflows in order to make them eligible to attract bank loans.

In conclusion, we strongly believe and affirm that ifall the ideas prompted here are strictly observed (and complied with) by all stakeholders in the value-added chain of agricultural production (farmers, agricultural research institutes, agricultural extension workers, commercial banks, monetary authorities, governments at all levels), policy of agricultural and industrial diversification by the Nigerian government would yield expected results which would enable Nigeria overcome her food sufficiency problem and have enough agricultural products to also export to other countries of the world to earn foreign exchange. This would positively contribute to increase in our foreign reserves.

\section{Note}

This paper drew elaborately from Sebastian 0. Uremadu's book, Core Bank Management: Concept and Applications, published by Precision Publishers Limited, Enugu, Nigeria, 2004, pp. $204-209$.

\section{References}

1. Uremadu SO (2004) Core Bank Management: Concepts and Applications, Precision Publishers Limited, Enugu, Nigeria.

2. Spencer MH (1962) Uncertainty, Expectations and Foundations on the Theory of Planning. Journal of the Academy of Management pp. 197206.

3. Uremadu SO (2000) Bank Management: Basic Issues in Money, Bank Lending and Credit Administration, Benin City: Mindex Publishing Company Ltd.

4. Uzoaga, WO (1987) Lecture Notes on Bank Management to final year students, Department of Finance, FBA, Enugu Campus, University of Nigeria, Nsukka, Nigeria.
Your next submission with Juniper Publishers will reach you the below assets

- Quality Editorial service

- Swift Peer Review

- Reprints availability

- E-prints Service

- Manuscript Podcast for convenient understanding

- Global attainment for your research

- Manuscript accessibility in different formats

( Pdf, E-pub, Full Text, Audio)

- Unceasing customer service

Track the below URL for one-step submission https://juniperpublishers.com/online-submission.php 